\title{
Communicating CSR practices - Role of Internationalization of Emerging Market Firms
}

\begin{abstract}
Emerging markets suffer from institutional voids, and in such resource deficient economies, corporate social responsibility is given scant attention. However, when firms from emerging markets globalize, international stakeholders become suspicious about firms' products, services and business practices. Grounded in the liability of emergingness and legitimacy theory and using a sample of 134 manufacturing firms from one emerging market, India, this study explores how firms' international diversification intent and market seeking motives influence emerging markets' firms communication of socially responsible activities as an attempt to eliminate illegitimacy. Furthermore, the study reveals that business group affiliation enhances the influence of internationalization on firms' communication of socially responsible activities.
\end{abstract}

Keywords Business group affiliation, CSR communication, Emerging markets, International diversification, Market seeking motive 
Communicating CSR Practices

$\begin{array}{ll}\text { Abbreviations } \\ \text { BG } & \text { Business Group } \\ \text { CSR } & \text { Corporate Social Responsibility } \\ \text { EMF } & \text { Emerging Market Firm } \\ \text { FDI } & \text { Foreign Direct Investment } \\ \text { GDP } & \text { Gross Domestic Product } \\ \text { LnAge } & \text { Natural Log of Age } \\ \text { LnSales } & \text { Natural Log of Total Sales } \\ \text { LOE } & \text { Liability of Emergingness } \\ \text { MLR } & \text { Multiple Linear Regression }\end{array}$




\section{Introduction}

Corporate social responsibility (CSR) practices of firms have been gaining significant traction among academics and practitioners. However, studies exploring determinants of CSR communication in emerging markets scarce (Gunawan 2016; Kühn et al. 2015). EMFs suffers from Liability of Emergingness (LOE). LOE refers to the adverse effects a firm faces in international markets because it belongs to an emerging market (Madhok and Kehyani 2012, p. 28; Marano et. al, 2016). Given that EMFs are internationalizing at fast pace (Xia et. al, 2014), despite challenges of LOE, we in this paper specifically enquire if strategic choices such as internationalization intent could drive EMFs to communicate their CSR activities in an attempt to overcome LOE.

Extant literature from developed markets indicates that firms communicate their CSR activities in response to institutional and stakeholder pressure (Gamerschlag e. al. 2011; Fernandez-Feijoo et al. 2014). However, resource scarcity and non-transparent business practices, makes institutional context of EMFs completely different (Khanna and Palepu 2006). Emerging markets like India are often ranked in the bottom half of the World Bank's "Ease of Doing Business" rankings (Doing Business, 2016). Even the low cost advantage of emerging markets is perceived to be driven by low wages, unsafe and unhealthy working conditions, and other unethical and socially exploitative business practices (Ioannau and Serafei 2012). All this leads to LOE (Bartlett and Ghoshal 2000). LOE could have important implications for communication of CSR activities by EMFs. We assert that firms' communication of CSR activities could be driven by a need to overcome LOE, especially when EMFs intend to internationalize. This is because CSR communication can help 
firms in gaining legitimacy among host country constituents (Pérez 2015) and subsequently overcome barriers associated with LOE (Amaladoss and Manohar 2013).

Hence, integrating LOE with corporate legitimacy theory, we specifically investigate three questions associated with drivers of CSR communication in emerging markets. First, how is EMFs' communication of CSR activities influenced by their intent to internationalize? We propose that EMFs are more likely to communicate their CSR practices in an attempt to overcome LOE, when they intend to internationalize. Once firms attain legitimacy amongst international stakeholders it might be easier for them to internationalize. Hence, we emphasize that EMFs proactively disclose CSR activities, once they decide to internationalize. Thus, internationalization intent drives communication of CSR activities amongst EMFs. This leads to our second research question. EMFs may choose to internationalize due to market-seeking or resource-seeking motives (Luo and Tung 2007). Do these motives have differential impacts on firms' intensity of communication of CSR activities? Here, we propose that the challenges of internationalization for EMFs are comparatively greater when they internationalize with market-seeking motives. International buyers lack trust in EMFs, hence they are less likely to buy products and services from these firms (Chiu and Wang 2015). Thus, in an attempt to gain legitimacy with potential industrial buyers or consumers in international markets, EMFs are more likely to communicate CSR activities, and hence overcome the adverse impact of LOE.

Our third research question is embedded in the institutional context of emerging markets. Business groups (BGs) are resource rich corporate parents with multiple lines of businesses, which evolved in emerging markets as a consequence of institutional voids and inefficient markets (Khanna and Palepu 2006). Hence, our third line of research, dealing with the institutional context, is: Can BG 
affiliation influence the impact of internationalization intent on firms' CSR communication practices in their home country? Since business groups are resource rich, they are better equipped to invest in socially responsible activities and enhance their social reputation. Furthermore, compared to standalone firms, BG-affiliated firms are more often charged with poor governance practices, such as tunneling off money through related party transactions or principal-principal conflicts (Khanna and Palepu 2006). Thus, they more greatly need to communicate socially responsible activities so as to maintain a legitimate image in international markets.

Based on a sample of 134 Indian manufacturing firms over a period of ten years (i.e., from 20052014), our study indicates that communication of CSR activities by EMFs is driven by their intent to internationalize. Furthermore, CSR communication increases when EMFs internationalize with market-seeking motives and represent an attempt to overcome LOE through enhanced legitimacy. Furthermore, BG affiliation enhances the impact of internationalization intent on communication of CSR activities.

Through this study, we primarily contribute to the CSR communication literature of emerging markets by explaining how communication of CSR activities is driven by EMFs' attempt to overcome LOE when they intend to internationalize, especially if they belong to business group. This is in contrast to extant literature which asserts that institutional voids leads to poor CSR practices. Our findings indicate that even poor institutional image could trigger CSR reporting. We thus suggest that CSR communication is an attempt to overcome LOE posed by weak characteristics of institutional voids, which specifically becomes important for EMFs when they intend to internationalize. Thus, otherwise EMFs may remain dormant for CSR initiative however, when they plan to internationalize then in an attempt to overcome LOE in international markets 
they disclose CSR activities. Our work also reflects extension of research dealing with institutional complexity (Greenwood et. al, 2011; Marano and Kostova, 2015) and springboard perspective (Luo and Tung, 2007) as our findings indicate how embeddedness of EMFs in a complex home country environment motivates them to communicate CSR practices, so as to gain legitimacy in international markets, when they intend to internationalize. Our study also adds to prior literature focused on constraining effects of LOE (Bartlet and Ghosal, 2000; Bangara et. al, 2012). We highlight how EMFs use CSR as a proactive legitimization tool when they plan to internationalize. Before internationalization strategy could be realized, EMFs signal positive and legitimate image globally so as to diminish negative effect of LOE. Thus, internationalization intent becomes a driving force for CSR communication.

Extant literature has emphasized stakeholder and institutional theories in driving communication of CSR activities of firms (Gamerschlag et al. 2011; Kühn et al. 2015; Thijssens 2015). In this regard, our study indicates that EMFs respond to international stakeholders' expectations when they intend to internationalize so as to overcome barriers imposed by LOE. Unless EMFs decide to internationalize, their image in international markets does not hamper business performance in their home country. Thus, role of institutional environment or stakeholders' expectations becomes vital for EMFs only when they intend to internationalize. Broadly, our study indicates the significant role that communication of CSR activities plays in diminishing stigma associated with belonging to an emerging market.

Furthermore, we highlight the significance of the motives for internationalization and the ownership structure of a firm in influencing the strength of the relationship between CSR communication and internationalization. Significance of market-seeking and resource-seeking 
motives is well known (Child and Rodrigues 2005). Through this study, we highlight how firms' internationalization intent drives them to communicate more CSR activities when they internationalize with market seeking motive. As LOE can discourage customers from purchasing products from EMFs, these firms communicate CSR activities in an attempt to attain legitimacy among consumers and overcome the LOE effect. Similarly, BGs in emerging markets are more influential in driving CSR reporting behavior of firms than standalone firms. Extant literature on CSR communication in emerging markets has overlooked the impact of BG affiliation (Li et al. 2010; Chaudhri and Wang, 2007). Our study covers this gap and asserts that due to resource munificence and an illegitimate image resulting from poor governance practices, BG-affiliated firms' communication of CSR activities are comparatively more driven by internationalization intent. Our findings thus reveal potential sources of successful international diversification of BG affiliated firms which is their ability to gain legitimacy in international markets.

BG affiliated firms capitalize on their existing resources or develop new resources in host country (Hoskisson et. al, 2004) as they are able to overcome LOE by virtue of utilizing their munificent resources in CSR activities and communicating the same to stakeholders. CSR communication is thus a proactive approach for EMFs especially BG affiliated firms, driven by the intended strategy of international diversification.

In the following sections, we first present a literature review and our theoretical framework, then a hypothesis section. Next, we explain our methodology and proceed to test our model empirically. Lastly, we explain our results, followed by our discussion, and a conclusion and managerial implications section. 


\section{Theory and Hypotheses}

CSR can be defined as:

"the process by which managers within an organization think about and discuss relationships with stakeholders as well as their roles in relation to the common good, along with their behavioral disposition with respect to the fulfillment and achievement of these roles and relationships" (Basu and Palazzo 2008, p. 124).

Several theoretical frameworks explain firms' motivations for communicating their CSR activities. The most commonly referenced theoretical frameworks are stakeholder theory, institutional theory, and legitimacy theory. According to the stakeholder theory and institutional theory frameworks, firms invest in and communicate CSR activities to respond to stakeholders and institutional pressures. In the emerging markets context, this pressure is virtually non-existent due to institutional voids (Khanna and Palepu 2006).

Emerging markets can be defined as countries "whose national economies have grown rapidly, where industries have undergone and are continuing to undergo dramatic structural changes, and whose markets hold promise despite volatile and weak legal systems" (Luo and Tung, 2007, p. 228). These weak legal systems and other non-transparent practices, arising out of resource scarcity in emerging markets, are collectively referred to as institutional voids (Khanna and Palepu 2006). Consequently, firms sometimes display irresponsible and illegitimate behavior, such as Satyam's financial scandal in India (Ghosh 2009) or Foxconn's exploitative labor practices in China (Lee 2014), leading to a poor business confidence index in these markets. Although 
institutional pressure does not exist for socially responsible activities, all EMFs in international markets bear the burden of the perceived backwardness and illegitimacy of their home countries (Hawn 2013). This disadvantage that EMFs suffer in international markets, compared to developed countries' firms, is known as Liability of Emergingness (LOE) (Madhok and Kayhani 2012).

EMFs thus face the prejudices of the host countries, due to the stigma of belonging to emerging markets (Held and Berg 2014). As a consequence of perceived poor credibility and legitimacy, international stakeholders may not find it conducive to initiate any business transactions with EMFs (Meyer et al. 2009; Fiaschi et al. 2015; Madhok and Kayhani 2012). This could be understood from the fact that non-materialization of cross border mergers and acquisition deals in India occurs twice as often as in the USA (Goyal 2013). For example, in 2006, the merger of Arcelor and Mittal steel was opposed by the French and Luxembourg governments due to a legacy of perceived poor business practices of firms having Indian roots, even though Mittal Steel was registered in Netherlands (The Economist, 2006).

\section{Communication of CSR Activities and Internationalization intent}

As long as EMFs operate within their home country, their poor image in international markets is not of prime concern for managers. However, when firms intend to internationalize, they need to overcome LOE through enhancing their perceived legitimacy (Bangara et al. 2012). Legitimacy theory asserts that there exists a social contract between organizations and society at large. Specifically, legitimacy is a "generalized perception or assumption that the actions of an entity are

desirable, proper, or appropriate within some socially constructed system of norms, values, beliefs, and definitions" (Suchmann 1995, p. 574). This implies that society has certain expectations from 
corporations with regard to the conduct of their business. These expectations range from moral obligations to maintenance of reciprocal relationships with stakeholders at large (Deegan and Unerman 2011). We specifically refer to the case of "pragmatic legitimacy" (Suchmann 1995, p. 577), in which legitimacy is aimed at influencing tangible returns in exchange for investment in developing a legitimate image. We assert that firms in emerging markets communicate their CSR activities in an attempt to gain legitimacy and overcome LOE among host country constituents when they intend to internationalize. Communication of CSR activities can help firms to increase their credibility and legitimacy among international stakeholders, which is of the utmost importance when EMFs intend to internationalize. Enhanced legitimacy can also overcome barriers associated with LOE (Fiaschi et al. 2015) and reflect EMFs' capability to fill institutional voids (Su et al. 2016).

Firms that communicate social responsibility reports to stakeholders likely do so with an expectation that a legitimate image would diminish the adverse effect of LOE (Nair et. al, 2015). Extant literature indicates that firms from developed economies also disclose their CSR activities to gain legitimacy when they have been charged with illegitimate operations (Zheng et. al, 2015). Even controversial industries, such as tobacco and gambling, have achieved legitimate images through reporting CSR activities (Oh et al. 2016; Gupta, 2015). This positive image can overpower the adverse effects that EMFs bear due to LOE (Reimann et al. 2012). Firms' which intend to internationalize are likely to be concerned about LOE. EMFs' communication of CSR activities is thus likely to be driven by internationalization intent in an attempt to mitigate LOE effect through enhancing legitimacy. Hence, we hypothesize H1: EMFs are more likely to disclose CSR activities when they intend to internationalize. 
Motives of Internationalization

A firm may intend to internationalize with market-seeking, resource-seeking or strategic assetseeking motives (Luo and Tung 2007). Market-seeking motive refers to internationalization with the objective of exploiting one's competitive advantage and hence increasing market share in the host country (Child and Rodrigues 2005). In resource-seeking foreign direct investment (FDI), a firm intends to acquire strategic assets or raw material to reduce the volatility of its operations, mostly in its home country (Buckley et. al, 2015).

As compared to the resource-seeking motive, the market-seeking motive has the more direct impact on the revenue earning capability of firms, as it deals with buyers' purchasing decisions and hence revenue potential. Thus, it is vital to focus on international buyers and their perception of EMFs since their purchasing decisions are likely to be influenced by the overall image of an EMF. As a consequence of poor image arising from LOE, customers may be hesitant to buy products from EMFs.

Existing studies in the social responsibility literature indicate a positive association between a firm's CSR and customers' outlook towards the firm (Homburg et al. 2013). The best companies around the world always audit the CSR practices of their potential suppliers before entering into any arrangement (Johnsen et al. 2014). Thus, when firms internationalize from emerging markets with LOE, communication of their individual ethical and social corporate activities becomes even more important. For instance, a Chinese supplier trying to internationalize in search of new buyers may experience LOE, as was the case when a Chinese supplier associated with Sodexo (a French 
food services and facilities management company) was found guilty of an E. Coli outbreak among 11,000 students in Germany due to non-adherence to hygiene standards. Similarly, a scandal involving toy company Mattel Inc., resulting from the use of lead paint in toys, made a dent in the reputation of all associated Chinese firms. As LOE of EMFs is created due to poor and unsafe manufacturing practices, a resulting image can be negated by socially responsible behavior (Fryzel 2014). Thus, from a legitimacy perspective, firms from emerging markets need to be even more aggressive and precise in communicating their socially responsible activities so as to diminish the adverse impact of LOE and positively influence customers' purchasing decisions from a given firm (Hume, 2010). Furthermore, since a market-seeking motive directly influences firms' profit earning potential in a host country, they are even more driven to disclose CSR in an effort to gain legitimacy and reduce the adverse impact of LOE.

Lastly, firms are likely to be more visible to customers when they internationalize to sell products and services in international markets, compared to when they internationalize to explore new assets or resources. Extant literature also indicates that firms behaved in a more CSR friendly manner when they exported products for international markets (Costa et. al, 2015). Some firms even used CSR as their differentiating strategy when venturing into international markets (Cruz et al. 2015). Similarly, Branco and Rodrigues (2006) also reported that banks that were more visible among customers were more active in the realm of social responsibility. In Taiwan also, customers were able to create pressure on international firms to disclose their socially responsible behavior (Huang and Kung 2010). Based on the above assertions, we hypothesize

H2: CSR communication practices are positively associated with the market-seeking motive of the firm. 


\section{Business Groups and CSR}

Business groups (BGs) evolved in emerging markets as a consequence of institutional voids and institutional inefficiencies in these markets (Khanna and Palepu 2000). BGs are corporate parents that are comparatively resource rich in resource scant emerging markets (Chang et al. 2006). BG affiliation leads to both positive and negative effects. Positive effects arise due to munificent resources and network advantage in home country. However, BG affiliation can also lead to negative effects. As compared to standalone firms, BG firms are more often charged with poor governance practices, as well as siphoning off financial and other capital resources from high performing to poor performing firms. This illegitimate image of $\mathrm{BG}$ firms pushes them to communicate CSR practices when they intend to internationalize.

Hence, BG-affiliated firms avail slack resources to gain legitimacy by investing in and more communicating their CSR activities. For example, in India, BG-affiliated firms are primarily located in less developed regions or states, and so they generate employment and raise standards of living (Fishman and Khanna 2004). Similarly, in China, BG-affiliated and non-state owned firms tend to facilitate institutional transition and report CSR activities (Li et al. 2013). Extant literature indicates that firms with slack resources were more likely to invest in and report CSR activities in an attempt to gain political and social legitimacy (Melo, 2012).

Consequently, as a joint effect of slack resources and poor governance practices, BG firms would be more driven to disclose CSR activities, in an effort to not only eliminate LOE, but also to improve legitimacy. Hence we hypothesize

H3: BG affiliation positively moderates the impact of the intent of internationalization on EMFs' communication of CSR activities. 


\section{Data and Methodology}

Our sample consisted of firms from two manufacturing sector industries: the automobile ancillary industry and pharmaceuticals industry. We selected some of the fastest growing manufacturing industries so as to reflect firms' earning opportunities within the domestic market. Despite high growth rates in the domestic market, if a firm chooses to internationalize, it is a reflection of strategic choice (Child 1997). Furthermore, we focused on the manufacturing sector, as it is an important driver of the Indian economy, contributing around $20 \%$ to the GDP of the country. Furthermore, by virtue of the nature of manufacturing, this sector has more social responsibility implications compared to the service sector. We focused on ten years of data only from 20052014; data on CSR activities prior to this period was difficult to obtain from archival sources. India is also an emerging market, where corporate parents like BGs are more prominent than in any other country (Khanna and Palepu 2006). Furthermore, post liberalization (i.e., after 1991) some Indian firms have aggressively diversified internationally and have even received the status of emerging markets multinationals (Khanna and Palepu 2006). Thus, it is interesting to explore if these firms overcame LOE effect challenges by behaving in a socially responsible manner in their home country.

We first considered all the firms categorized as drugs or pharma and automobile its ancillary by Prowess (a financial database on Indian companies). This resulted in a population of 626 firms. Following the approach of Elango and Patnaik (2013), we restricted our sample size to only those firms that exhibited average sales of at least one million US dollars in the given time frame, 20052014. Furthermore, we removed firms with missing financial data during the time period, as well 
as government-owned firms or subsidiaries of foreign multinationals. Thus, after filtering the data based on these parameters, we obtained a sample of 134 firms.

Operationalization of Variables

Dependent variable: To assess communication of CSR activities, we considered the annual reports and social responsibility reports published by firms every year. A checklist of CSR items was generated based on extant studies conducted in India (Kansal et al. 2014). This resulted in an extensive list of 96 items. This list also included some Indian-specific socially responsible activities, like reservation to minority communities, midday meals for children, or mass marriage programs. The complete list of CSR themes and their corresponding items used in the present study are in Appendix A.

Scoring method: Each of the 96 CSR items was scored on a dichotomous scale. Thus, if an item in the checklist was disclosed in a CSR or annual report of the firm, it was coded as 1; otherwise, it was coded as 0 (Ghazali 2007). An issue was considered as reported by a firm, if the report described specific actions taken by that firm to address a particular issue. If only issue was mentioned in some context without any description of firms' efforts to address that issue, it was not considered to be a part of CSR communication index. One of the authors coded all of the sustainability/CSR/ annual reports. Another researcher randomly selected 100 reports and recoded them. Inter-rater reliability assessed in terms of Cohens' kappa was 0.78 , indicating a moderately acceptance level. Next, a CSR communication index was calculated as a ratio of total number of actual disclosures made by firm and total number of disclosures actually possible, i.e., 96. 
Independent variables

Internationalization intent: Firms' communication of CSR activities in year $\mathrm{X}_{\mathrm{t}}$ would be driven by is internationalization intent in year $\mathrm{X}_{\mathrm{t}-1}$. As through secondary research we cannot directly capture firms' intended strategy, it can be best captured through its realized strategy (Ferrell and Hartline 2012). However, there is always a time difference between intended strategy and realized strategy (Andersen and Nielsen 2009). It was assumed that firms' internationalization intent in year $X_{t}$ would be realized after three years, i.e., $X_{t+3}$. A three-year time period has been consistently used to gauge the impact of firms' strategy on performance (Lahiri and Narayanan 2013). Thus, this time period can also reflect the time a firm may require to realize its intended strategy. Hence, to capture firms' communication of CSR activities in 2005, internationalization intent was considered for the year 2004, and it was operationalized as the ratio of foreign investments to total assets of the firm (Chari 2013) for the year 2007. The data was obtained from Prowess, CMIE, which is a database of Indian companies. Thus, CSR activities were captured from 2005-2012 and internationalization intent from 2004-2011, operationalized as actual foreign investment from 2007-2014.

Market-seeking/resource-seeking/multiple motives: In this study, a firm's market-seeking motive is referred to when it internationalizes with the main objective of expanding its international market. All other motives, i.e. assets/efficiency-seeking, were classified as resource-seeking motives in this paper. We considered annual reports and other web-based resources, namely newspaper articles and trade journals in which interviews with the top management of the firms or reports by industry analysts were published. We then analyzed these materials to determine the 
motives of internationalization, i.e., whether the motive is marketing-seeking or resource-seeking. For example, when in 2007 Wockhard Limited acquired Negma Laboratories of France, it was acquired by Wockhardt with an intent to expand its patented portfolio of drugs to European markets (Evaluate.com, 2007). So this was treated as market seeking motive.

Hence, if in a particular year, firms internationalized largely due to a market-seeking motive, it was coded as one. If they were focused on resource seeking, it was coded as zero. Motive was coded as market seeking or resource seeking by one of the authors. To check the reliability of the content analysis, $30 \%$ of the randomly selected reports and web-based articles was cross-checked by another researcher. Consistency of coding was reported in $89 \%$ of the cases.

$B G$ affiliation: This was captured as a dummy variable, with 1 indicating that the firm was affiliated with a BG and 0 indicating that the firm was standalone. The data was obtained from Prowess.

Interaction effect of internationalization and BG affiliation: To operationalize the moderating effect, we used the mean centering effect so as to nullify the problem of multicollinearity (Shieh, 2011). Thus, we calculated the mean of the FDI to asset ratio and BG affiliation, and subtracted the individual values of the FDI to asset ratio and group affiliation from their respective mean value. Values of the FDI to asset ratio and BG affiliation so obtained were then multiplied with each other.

Control variables: We controlled for firm size and age (Giannarakis 2014) as they have been found to positively influence firms' communication of CSR activities. Firm size was measured as the natural $\log$ of total sales (LnSales) of the firm. Similarly, firm age variability was also reduced by 
taking its natural $\log (\mathrm{LnAge})$. Data for both firm age and size were obtained from Prowess. Lastly, to control for industry effects (Grougiou et al. 2016; Young and Marais 2012), the drugs and pharma industry was dummy coded as 1 and the automobile ancillary industry as 0 . Apart from this, we also controlled for firms' financial performance, as it has been found to impact firms' CSR activities ((Julian \& Ofori-dankwa, 2013; McWilliams and Siegel, 2000). Performance was captured as Return on Assets, i.e. ratio of net income to total assets, information on which was obtained from Prowess.

Methods

We used multiple linear regression (MLR) to conduct our analysis, which is given below:

$\mathrm{CSR}_{\mathrm{i}, \mathrm{t}}=\beta_{0}+\beta_{1}$ Internationalization $_{\text {intent }_{\mathrm{i}, \mathrm{t}-1}}+\beta_{2}$ Internationalization $_{\text {motive }} \mathrm{i,t-1}+\beta_{3}$ $\mathrm{BG}^{*}$ Internationalization intent $\mathrm{i}_{\mathrm{i}-\mathrm{-}-1}+\beta_{4}$ firm size $_{\mathrm{i}, \mathrm{t}-1}+\beta_{5}$ firm age $_{\mathrm{i}, \mathrm{t}-1}+\beta_{6} \mathrm{BG}_{\mathrm{i}, \mathrm{t}-1}+\beta_{7}$ Industry $_{\mathrm{i}, \mathrm{t}-1}+\mathrm{u}$

\section{Results}

Table 1 shows the descriptive statistics with the Pearson correlation coefficients among the dependent variables, independent variables, and the control variables. Since the correlation coefficient among the independent variables is below the value of 0.50 , there are no signs of multicollinearity (Hair et al. 2010). Furthermore, positive and statistically significant correlation coefficients between communication of CSR activities and the two independent variables, internationalization intent and its motive, can be observed. Among the control variables, a positive and significant correlation between firm size and communication of CSR activities exists. 
Correlation analysis provides some preliminary insights about the significance of the relationship between CSR and internationalization. Through MLR analysis, we present a detailed look at the effect of the independent variables on the communication of CSR activities of Indian firms. Table 2 reports the results of the MLR. Overall, no evidence was observed to reject our hypotheses. The results regarding firm size as a control variable are in agreement with extant literature, in which sales by virtue of size of firm were found to impact firms' CSR communication behavior (Morhardt 2010). However, no significant differences between the impact of industry on CSR communication were observed, unlike in some earlier studies. This could be because both industries belong to the manufacturing sector and contribute adversely to both environmental and social issues, such as safe workplace practices. Hence their level of disclosure does not vary much due to industry differences. Profitability in corroboration with extant studies was found to significantly impact communication of CSR activities of EMFs.

\section{Insert Table 1 about here}

\section{Insert Table 2 about here}

Our first hypothesis states that there is a positive association between firms' internationalization intent and communication of CSR activities. According to Model 2 of Table 2, since the beta 
coefficient of the Foreign investment to asset ratio is positive and significant $(\beta=0.06, p<0.001)$, we find evidence in support of the first hypothesis. This implies that as a firm's intent to internationalize increases, its communication of CSR activities also increases. Given that EMFs suffer from LOE, by communicating CSR activities, EMFs intend to enhance their legitimate image and hence overcome LOE barriers. The findings of this study are in corroboration with extant studies, in which a positive association was found between CSR and firms' internationalization (Cheung et al. 2015; Marano et al. 2016).

The second hypothesis stated that firms would communicate more CSR activities if they internationalize due to a market-seeking motive. Since the beta coefficient of the market-seeking motive is positive and significant $(\beta=0.19, \mathrm{p}<0.001)$, evidence in support of the second hypothesis was observed as well. This implies that when Indian firms are internationalizing as suppliers to seek new buyers, they are even more aggressive in disclosing their CSR activities. Extant literature indicates that international buyers in general are very cautious about their suppliers' CSR practices and regularly audit these practices (Baden et al. 2009). Thus, they are likely to be even more careful when they have to select a supplier from a country that suffers from LOE. Findings of the present study provide support to this argument, as Indian firms while internationalizing due to a marketseeking motive are seeking legitimacy among potential buyers through communication of CSR activities.

The third hypothesis stated that BG affiliation moderates the relationship between the communication of CSR activities and the intent of internationalization. The beta coefficient of the interaction effect of BG affiliation and the FDI to asset ratio is positive and significant, and we thus find evidence in support of the third hypothesis as well $(\beta=0.03, \mathrm{p}<0.001)$. This implies that 
when a firm is affiliated with a BG and intends to internationalize, it will communicate more CSR activities compared to standalone firms. In other words, the ownership structure of a firm influences the relationship between CSR and internationalization. Thus, the present study's findings are again in corroboration with extant studies conducted in emerging markets where CSR communication was found to be influenced by the ownership structure of the firm (Oh et al. 2015).

\section{Discussion}

This study examines determinants of the communication of CSR activities of Indian firms. CSR communication has received comparatively less attention in emerging markets, despite the increasing economic significance of emerging markets (Khan et al. 2013). Using an integrated theoretical framework of LOE and legitimacy theories, we provide evidence that the internationalization intent of EMFs, especially Indian firms, drives them to communicate their CSR activities. Our findings are thus, counter to mainstream arguments, as per which EMFs CSR practices are driven by home country institutional environment (Halaszovich, T. F., \& Lundan, 2016). As our findings indicate that EMFs indulge in and hence communicate CSR practices even if such practices are not enforced by weak institutional environment of emerging markets.

We assert that firms do so with a motive to mitigate the negative effect of LOE through legitimate gains from CSR activities. The adverse effects of LOE arise since emerging markets have underdeveloped economic and institutional infrastructure. This consequently leads to poor ethical and governance business practices (Bell et al. 2008). Hence, host country constituents develop negative stereotype and beliefs about products, services, and business practices of firms associated 
with emerging markets (Goedhuys, M., \& Sleuwaegen, 2016). Firms can combat this LOE by gaining legitimacy through CSR practices. Recent literature indicates that firms in developing countries are more detailed in reporting CSR activities compared to developed market firms (Barakat et. al, 2015). This could be an attempt to overcome LOE. We assert that EMFs would be more concerned with LOE, when they have intent to internationalize. Thus, EMFs with internationalization intent are more likely to disclose CSR in an attempt to overcome LOE.

As per our results, CSR communication behavior is even more driven by the market-seeking motive of internationalization, as compared to the resource-seeking motive. Unlike when a resource-seeking motive influences internationalization, and host country constituents' purchasing is not directly impacted, when firms are influenced by a market-seeking motive, the buying decisions of international customers are directly impacted. Firms perceived as illegitimate are less likely to be preferred by buyers. Thus, firms' internationalization intent with market seeking motive raises its CSR communicative practices.

Our study also indicates that the internationalization intent of BG-affiliated firms drives CSR reporting behavior among EMFs more, as compared to standalone firms. This happens because they are comparatively resource rich, and apart from the effects of LOE, they bear the additional burden of an illegitimate image due to poor governance practices. Thus, they need to invest in and then disclose even more socially responsible behavior so as to convince international stakeholders. This reflects a new perspective on business groups in India, as extant studies on CSR communication behavior have largely ignored the role of business group affiliation (Mishra and Suar 2010). 
Our study contributes to a deeper understanding of the communication of CSR practices by EMFs, especially Indian firms. Thus, we first add to the literature on EMFs CSR communication practices. Extant research suggests that institutional voids at home country propels EMFs to diversify internationally in search of resources and markets (Luo \& Tung, 2007). However, this search can be successful only if EMFs opt for appropriate legitimation strategies. Communicating CSR activities is one way of portraying legitimate image. EMFs need to depict legitimate image prior to internationalization as institutional voids results in LOE (Bangara et. al, 2012), which can be an obstacle while internationalizing. To counter this adverse liability perceived by host countries and global stakeholders, EMFs proactively engage in CSR practices, even if weak institutional environment does not forces them to do so.

Hence, we extend the literature on the relationship between international diversification and CSR by providing evidence from emerging markets, about which literature is scant as compared to developed markets (Ma et al. 2016). Second, we provide evidence of non-financial drivers of communication of all types of CSR activities in EMF, especially India. Extant studies in the emerging markets context have either explored only one specific aspect of CSR practices, such as environmental issues (Hossain and Reaz 2007), or have focused on firm-specific financial factors, such as firms' liquidity or assets in driving CSR behavior (Kansal et al. 2014; Cheng et. al, 2014). By virtue of focusing on the communication of the entire gamut of CSR activities and non-financial factors driving firms to CSR reporting, such as the intent and motives of internationalization, the present study overcomes these two limitations and hence contributes to a strategic view of CSR (McWilliams et. al, 2006). Furthermore, extant literature has mainly relied on institutional and stakeholder theories to explain CSR reporting practices among firms (Chiu and Wang 2015; Park 
et. al, 2015). We assert that LOE and legitimacy are also appropriate theoretical foundations in explaining EMFs' motives for CSR communicative practices.

Third, by examining how Indian firms' CSR communication behavior is driven by the marketseeking motive of internationalization, we extend prior literature on CSR communication practices in which scholars have emphasized the role of international buyers in driving the CSR activities of firms (Azizul Islam and Deegan, 2008). Our study thus aims at providing a better understanding of how communication of CSR activities can help EMFs overcome their LOE and thus gain legitimacy in international markets (Madhok and Kayhani, 2012). Our results with regard to BG affiliation are in alignment with studies in other emerging markets where the ownership structure has been reported to have significant influence on firms' CSR reporting practices (Campopiano and De Massis 2015; Oh et al. 2015)

\section{Managerial Implications and Future Research}

It has been found that managers from developing economies have a comparatively less favorable attitude toward CSR practices (Moyeen and West 2014). This may happen because of less institutional pressure that EMFs face as a consequence of institutional voids (Diebecker and Sommer, 2015). Our study indicates that reporting CSR practices could be a strategic need for EMFs. This implies that not only should they invest in CSR activities, but they should also strategically communicate their investment in such activities. Effective CSR communication is an appropriate way to mitigate the negative impact of LOE through legitimacy enhancing 
socially responsible activities ( $\mathrm{Li}$ et al. 2010). As beta coefficients though statistically significant, yet are small, we do not assert that CSR communication alleviates all legitimacy challenges for EMFs based on LOE. However yet it could be beneficial for EMFs as such communication practices improves their reputation globally and further pushes them to analyze, investigate and consequently improve actual CSR practices (Marano and Tashman, 2012).

Managers consider consumers to be one of their most important stakeholders (Park and Ghauri 2015). Thus, communicating CSR practices becomes even more important when managers intend to internationalize due to a market-seeking motive. Customers are unlikely to buy products from EMFs, as they conceive them to be of poor quality. Tainted milk and lead toys scandal in China, adulterated food items in India, exploitative child labor practices, etc. have further diminished the image of EMFs among potential international customers. By disclosing socially responsible behavior to international consumers, EMFs can attempt to fulfill their market-seeking motive, as legitimacy gained through socially responsibly activities can potentially overcome LOE (VidaverCohen and Colwell 2015). The significance of the market-seeking motive is in alignment with extant literature as well, which documents firms that have been advertising their CSR efforts to influence consumers' attitudes and purchase intention towards their brands (Perks et. al, 2013). Managers working for BG-affiliated firms need to be even more wary when disclosing their CSR activities. Not only do these managers have more resources, but also they must contend with an even more negative image with regard to business practices. Due to this poor image, even some reputable BGs in India, such as Tata Steel, have faced problems while internationalizing (The Economist 2011). Thus, BG-affiliated firms' managers even more greatly need to communicate 
their CSR activities in an attempt to not only overcome LOE, but also to improve an illegitimate business image.

Though our study has several contributions to the CSR communication literature, it also suffers from several limitations. In this research, we cover only one fast growing emerging market, India. However, our findings cannot be generalized to other emerging markets. Thus, the impact of internationalization intent on communication of CSR activities should be explored in other emerging markets as well. Also, though we followed extant literature in covering the entire gamut of CSR activities, nevertheless the communication index does involve some degree of subjectivity, which we cannot control for. Lastly, recent literature indicates that firms unduly exaggerate their CSR communication (Kim and Lyon 2014). Thus, there is a possibility of decoupling between disclosed and actually practiced CSR activities. We cannot control for this effect, and we interpreted all disclosures made by firms as genuine.

Future research could investigate how the motives of internationalization impact firms' socially responsible behavior in a host country. Firms that internationalize due to a market-seeking motive might behave in a more socially responsible manner in their host country as well. Similarly, CSR communication practices of BG-affiliated firms could differ from standalone firms in the host country as well. Yet another aspect that could be explored in the future includes comparing institutional differences in CSR activities, e.g. if EMFs localize or globalize their CSR agendas. Even performance implications of legitimacy driven CSR practices would be worthy to investigate in future research. Similarly, legitimacy driven benefits from communication of CSR practices can also be used to explore its impact on stock market performance of firm, its cost of capital, lawsuits against firm etc. Similarly, other approaches to gain legitimacy with global stakeholders could 
Communicating CSR Practices

also be explored in future research. Evidence indicates that EMFs are adopting best practices in all management areas including HRM, marketing or product development amongst others (McKinsey and Company, 2005). Differential impact of these approaches to gain legitimacy could be investigated in future research. 
Appendix A: List of CSR activities based on Kansal et. al (2014) study

\begin{tabular}{|c|c|}
\hline Theme & Item \\
\hline \multirow{16}{*}{$\begin{array}{l}\text { Community } \\
\text { Development }\end{array}$} & Promotion of education through donations/scholarships \\
\hline & Summer or part-time employment of students \\
\hline & Sponsorship of educational conferences, seminars, and art exhibits \\
\hline & Sponsorship of public health projects/medical camps \\
\hline & Aiding medical research \\
\hline & Supporting national pride and government campaigns \\
\hline & $\begin{array}{l}\text { Supporting the development of local industries or community programs and } \\
\text { activities }\end{array}$ \\
\hline & Generation of jobs \\
\hline & Establishment/maintenance of educational institutions \\
\hline & Formulating vigilance committee to check corruption in the company \\
\hline & Livestock/wasteland development \\
\hline & Providing relief to victims of natural disasters \\
\hline & Employee volunteerism for community work \\
\hline & Rural development program/adoption of villages \\
\hline & Rainwater harvesting \\
\hline & Improving road network \\
\hline
\end{tabular}


Improving agricultural productivity

\begin{tabular}{|c|}
\hline Aids to sports \\
\hline Meals for the disabled/midday meals for children \\
\hline $\begin{array}{c}\text { Special community related activities, e.g. opening the company's facilities to } \\
\text { the public }\end{array}$ \\
\hline Adopting old age homes \\
\hline Mass marriage programs \\
\hline
\end{tabular}

\begin{tabular}{|c|c|}
\hline Theme & Item \\
\hline \multirow{19}{*}{ Human Resources } & Statements regarding reduction of pollutants, irritants, hazards, injuries \\
\hline & Promoting employee safety and physical or mental health \\
\hline & Compliance with health and safety standards and regulations \\
\hline & Receiving a safety award \\
\hline & Establishing a safety department/committee/safety policy \\
\hline & Providing low cost health care for employees \\
\hline & $\begin{array}{l}\text { Disclosing percentage or number of minority employees in the workforce } \\
\text { and/or in the various managerial levels }\end{array}$ \\
\hline & Employment of differently abled people/ex-servicemen \\
\hline & Training employees through in-house program \\
\hline & $\begin{array}{l}\text { Giving financial assistance to employees in educational institutes or } \\
\text { continuing education courses }\end{array}$ \\
\hline & Establishment of trainee centers \\
\hline & Staff accommodation \\
\hline & Providing recreational, cultural and activities/facilities \\
\hline & $\begin{array}{l}\text { Providing the number of employees in the company and/or at each } \\
\text { branch/subsidiary }\end{array}$ \\
\hline & $\begin{array}{c}\begin{array}{l}\text { Providing per employee statistics, e.g. assets per employee and sales per } \\
\text { employee }\end{array} \\
\end{array}$ \\
\hline & $\begin{array}{c}\text { Providing information on the company/management's relationships with the } \\
\text { employees in an effort to improve job satisfaction and employee motivation } \\
\text { e.g. Strikes/statements regarding cordial relations }\end{array}$ \\
\hline & $\begin{array}{c}\text { Improvements to the general working conditions - both in the factories and } \\
\text { for the office staff }\end{array}$ \\
\hline & Information and statistics on employee turnover \\
\hline & Information and statistics on employee turnover \\
\hline
\end{tabular}




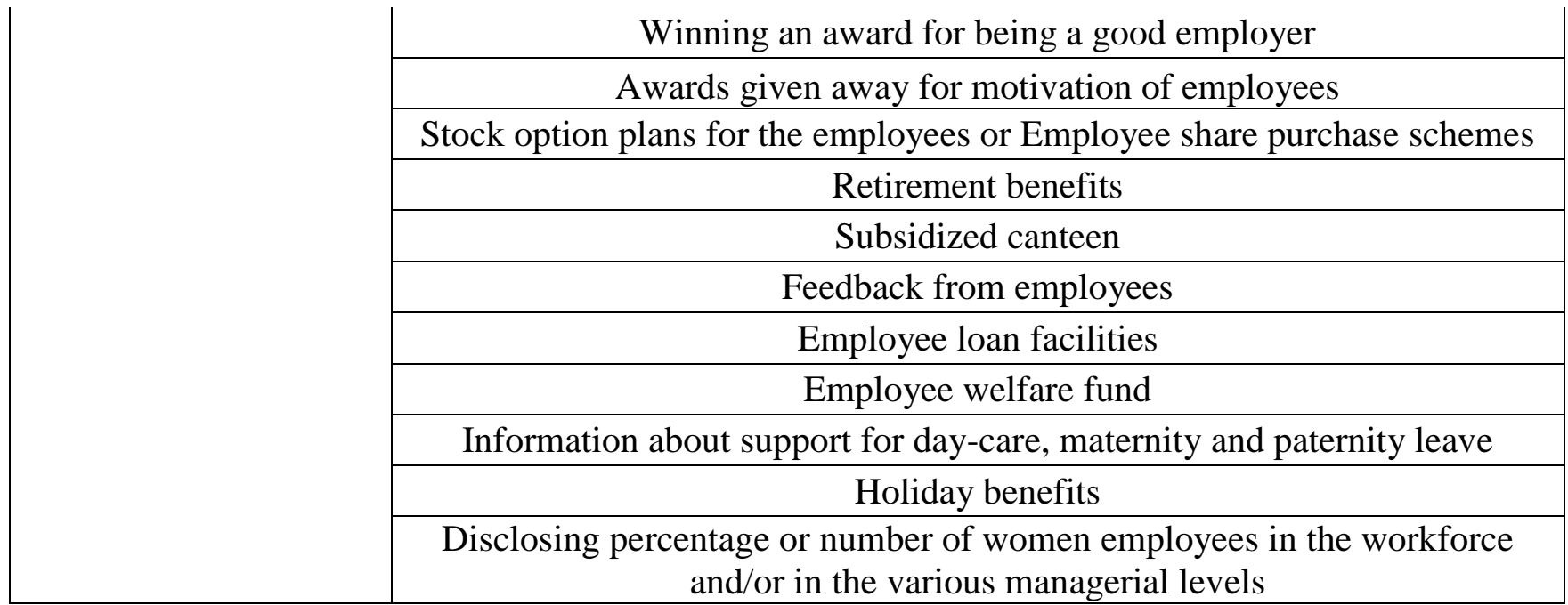

\begin{tabular}{|c|c|}
\hline Theme & Item \\
\hline \multirow{6}{*}{$\begin{array}{l}\text { Products, Services - } \\
\text { Safety and Innovation }\end{array}$} & $\begin{array}{c}\text { Information on developments related to the company's products, including its } \\
\text { packaging, e.g. making containers reusable }\end{array}$ \\
\hline & $\begin{array}{l}\text { The amount/percentage figures of research and development expenditure for } \\
\text { specific products and/or its benefits }\end{array}$ \\
\hline & $\begin{array}{c}\text { Information on the quality of the firm's products as reflected in prizes/awards } \\
\text { received }\end{array}$ \\
\hline & Verifiable information that the quality of the firm's product has increased \\
\hline & $\begin{array}{l}\text { Disclosing improved or more sanitary procedures in the processing and } \\
\text { preparation of products }\end{array}$ \\
\hline & Information on the safety of the firm's product \\
\hline \multirow{8}{*}{ Environment } & $\begin{array}{l}\text { Pollution consciousness in conduct of Business operations (capital, operating, } \\
\text { R\& D for pollution abatement) }\end{array}$ \\
\hline & $\begin{array}{l}\text { Statements indicating that the company's operations are non-polluting or that } \\
\text { they are in compliance with pollution laws and regulations }\end{array}$ \\
\hline & $\begin{array}{c}\text { Statements indicating that pollution from operations have been or will be } \\
\text { reduced }\end{array}$ \\
\hline & $\begin{array}{l}\text { Prevention or repair of damage to the environment resulting from processing } \\
\text { or natural resources, e.g. land reclamation or reforestation }\end{array}$ \\
\hline & $\begin{array}{l}\text { Conservation of natural resources, e.g. recycling glass, metals, oil, water and } \\
\text { paper; using recycled materials }\end{array}$ \\
\hline & Preventing waste/ waste management \\
\hline & Biodiversity/wildlife conservation \\
\hline & $\begin{array}{l}\text { Signatory status to agreements that commit the organization to consider the } \\
\text { environment in its operations }\end{array}$ \\
\hline
\end{tabular}


Water, environment studies/surveys

Water reuse/reduction of water usage

Use of environment friendly materials

Claims that the company is water positive/targets to become water positive

Discussion of environment management systems

Donations for restoring historical buildings/structures

receiving an award for environment programs and policies

\begin{tabular}{|c|c|}
\hline Theme & Item \\
\hline \multirow{7}{*}{ Energy } & $\begin{array}{c}\text { Conservation of energy in the conduct of business operations/using energy } \\
\text { more efficiently during the manufacturing process }\end{array}$ \\
\hline & Use of alternate sources of energy \\
\hline & Discussing the company's efforts to reduce energy consumption \\
\hline & Receiving an award for an energy conservation program \\
\hline & Disclosing the company's energy policies \\
\hline & Voicing concerns about energy shortages \\
\hline & Energy conservation/day week/month/awareness \\
\hline \multirow{9}{*}{$\begin{array}{l}\text { Emission of Carbon } \\
\text { and Harmful gases }\end{array}$} & Setting Carbon emission targets \\
\hline & Disclosing mode used for reducing carbon emission \\
\hline & Statements showing that emissions within the limits \\
\hline & Efforts to reduce carbon emissions \\
\hline & Clean development management project (use of clean technology) \\
\hline & Carbon emission management system \\
\hline & Green building movement \\
\hline & Statements that company is carbon positive \\
\hline & natory to MOU with other corporate with regard to reduction of \\
\hline
\end{tabular}




\begin{tabular}{|c|c|}
\hline \multirow{4}{*}{ Other CSR activities } & $\begin{array}{c}\text { Membership of United Nation Global Compact (UNGC) Program } \\
\text { Corporate objectives/policies: general disclosure of corporate } \\
\text { objectives/policies relating to the social responsibility of the company to the } \\
\text { various segments of society }\end{array}$ \\
\cline { 2 - 3 } & $\begin{array}{c}\text { Receiving CSR rewards } \\
\text { Social accounting system audit }\end{array}$ \\
\cline { 2 - 3 } & $\begin{array}{c}\text { CSR or part of CSR as a theme on title page/part of company mission/vision } \\
\text { statement }\end{array}$ \\
\cline { 2 - 3 } & Encouragement to implement official language \\
\cline { 2 - 3 } & Issuance of value added statements \\
\hline
\end{tabular}

\section{References}

Amaladoss, M. X., \& Manohar, H. L. (2013). Communicating corporate social responsibility-A case of CSR communication in emerging economies. Corporate Social Responsibility and Environmental Management, 20(2), 65-80.

Andersen, T. J., \& Nielsen, B. B. (2009). Adaptive strategy making: The effects of emergent and intended strategy modes. European Management Review, 6(2), 94-106.

Azizul Islam, M., \& Deegan, C. (2008). Motivations for an organisation within a developing country to report social responsibility information: Evidence from Bangladesh. Accounting, Auditing \& Accountability Journal, 21(6), 850-874. 
Baden, D. A., Harwood, I. A., \& Woodward, D. G. (2009). The effect of buyer pressure on suppliers in SMEs to demonstrate CSR practices: an added incentive or counterproductive? European Management Journal, 27(6), 429-441.

Bangara, A., Freeman, S., \& Schroder, W. (2012). Legitimacy and accelerated internationalisation: An Indian perspective. Journal of World Business, 47(4), 623-634.

Barakat, F. S., Pérez, M. V. L., \& Ariza, L. R. (2015). Corporate social responsibility disclosure (CSRD) determinants of listed companies in Palestine (PXE) and Jordan (ASE). Review of Managerial Science, 9(4), 681-702

Bartlett, C. A., \& Ghoshal, S. (2000). Going global: Lessons from late movers. Harvard Business Review, 78(2), 132-142.

Basu, K., \& Palazzo, G. (2008). Corporate social responsibility: A process model of sensemaking. Academy of management review, 33(1), 122-136.

Bell, R. G., Moore, C. B., \& Al-Shammari, H. A. (2008). Country of origin and foreign IPO legitimacy: Understanding the role of geographic scope and insider ownership. Entrepreneurship Theory and Practice, 32(1), 185-202.

Branco, M. C., \& Rodrigues, L. L. (2006). Corporate social responsibility and resource-based perspectives. Journal of Business Ethics, 69(2), 111-132. 
Buckley, P. J., Munjal, S., Enderwick, P., \& Forsans, N. (2015). Cross-border acquisitions by Indian multinationals: Asset exploitation or asset augmentation?. International Business Review.

Campopiano, G., \& De Massis, A. (2015). Corporate social responsibility reporting: A content analysis in family and non-family firms. Journal of Business Ethics, 129(3), 511-534.

Chaudhri, V., \& Wang, J. (2007). Communicating corporate social responsibility on the internet a case study of the top 100 information technology companies in India. Management Communication Quarterly,21(2), 232-247.

Park, B. I., Chidlow, A., \& Choi, J. (2014). Corporate social responsibility: Stakeholders influence on MNEs' activities. International Business Review,23(5), 966-980.

Chang, S. J., Chung, C. N., \& Mahmood, I. P. (2006). When and how does business group affiliation promote firm innovation? A tale of two emerging economies. Organization

Science, 17(5), 637-656.

Chari, M. D. (2013). Business groups and foreign direct investments by developing country firms: An empirical test in India. Journal of World Business, 48(3), 349-359.

Cheung, Y. L., Kong, D., Tan, W., \& Wang, W. (2015). Being good when being international in an emerging economy: The case of China. Journal of Business Ethics, 130(4), 805-817. 
Cheng, B., Ioannou, I., \& Serafeim, G. (2014). Corporate social responsibility and access to finance. Strategic Management Journal, 35(1), 1-23.

Child, J. (1997). Strategic choice in the analysis of action, structure, organizations and environment: retrospect and prospect. Organization studies, 18(1), 43-76.

Child, J., \& Rodrigues, S. B. (2005). The internationalization of Chinese firms: A case for theoretical extension? Management and Organization Review, 1(3), 381-410.

Chiu, T. K., \& Wang, Y. H. (2015). Determinants of social disclosure quality in Taiwan: An application of stakeholder theory. Journal of Business Ethics, 129(2), 379-398.

Costa, C., Lages, L. F., \& Hortinha, P. (2015). The bright and dark side of CSR in export markets: Its impact on innovation and performance. International Business Review, 24(5), 749-757.

Cruz, L. B., Boehe, D. M., \& Ogasavara, M. H. (2015). CSR-based differentiation strategy of export firms from developing countries: An exploratory study of the strategy tripod. Business \& Society, 54(6), 723-762.

Deegan, C., \& Unerman, J. (2011). Financial accounting theory. McGraw-Hill, Sydney 
Diebecker, J., \& Sommer, F. The impact of corporate sustainability performance on information asymmetry: the role of institutional differences. Review of Managerial Science, 1-47.

Doing Business (2016). Ease of doing business in India. Retrieved March 5, 2016, from http://www.doingbusiness.org/data/exploreeconomies/india/

Elango, B., \& Pattnaik, C. (2013). Response strategies of local firms to import competition in emerging markets. Journal of Business Research, 66(12), 2460-2465.

Evaluategroup.com (2007). Wockhardt acquires Negma Laboratories. Retrieved October 8, 2015 from, http://www.evaluategroup.com/Universal/View.aspx?type=Story\&id=126467

Fernandez-Feijoo, B., Romero, S., \& Ruiz, S. (2014). Effect of stakeholders' pressure on transparency of sustainability reports within the GRI framework. Journal of Business Ethics, 122(1), 53-63.

Ferrell, O. C., \& Hartline, M. (2012). Marketing strategy. Cengage Learning, Mason (OH).

Fiaschi, D., Giuliani, E., \& Nieri, F. (2015). BRIC companies seeking legitimacy through corporate social responsibility. Retrieved December 12, 2015, from http://papers.ssrn.com/sol3/papers.cfm?abstract_id=2559110 
Fishman, R. and Khanna, T. (2004). Facilitating development: The role of business groups. World Development, 32(4), 609-28.

Fryzel, B. (2014). The true value of CSR: Corporate identity and stakeholder perceptions. Palgrave Macmillan, New York (NY).

Gamerschlag, R., Moller, K., \& Verbeeten, F. (2011). Determinants of voluntary CSR disclosure: Empirical evidence from Germany. Review of Managerial Science, 5(2-3), 233-262.

Ghazali, N. A. (2007). Ownership structure and corporate social responsibility disclosure: Some Malaysian evidence. Corporate Governance: The International Journal of Business in Society, 7(3), 251-266.

Ghosh, S. (2009). Satyam scam: Will PwC be punished for lapses? Retrieved September 23, 2015, from http://articles.economictimes.indiatimes.com/2009-01-24/news/27653809_1_auditing$\underline{\text { satyam-fraud-satyam-scam }}$

Giannarakis, G. (2014). Corporate governance and financial characteristic effects on the extent of corporate social responsibility disclosure. Social Responsibility Journal, 10(4), 569-590 
Goyal, M. (2013). Apollo-Cooper tire deal in trouble: Why some big bang M\&A proposals never

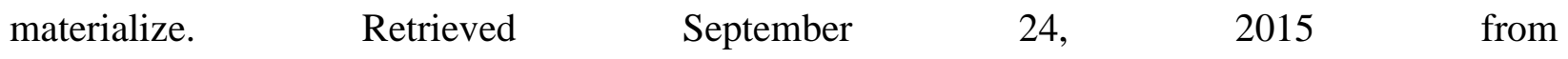
http://articles.economictimes.indiatimes.com/2013-10-13/news/42993127_1_apollo-tyrescooper-tire-rubber-kanwars

Goedhuys, M., \& Sleuwaegen, L. (2016). International standards certification, institutional voids and exports from developing country firms. International Business Review.

Grougiou, V., Dedoulis, E., \& Leventis, S. (2016). Corporate social responsibility reporting and organizational stigma: The case of "Sin" industries. Journal of Business Research, 69(2), 905-914.

Gunawan, J. (2016). Corporate Social Responsibility Initiatives in a Regulated and Emerging Country: An Indonesia Perspective. In Key Initiatives in Corporate Social Responsibility (pp. 325340). Springer International Publishing.

Gupta, S. (2015). A conceptual framework that identifies antecedents and consequences of building socially responsible international brands. Thunderbird International Business Review. Halaszovich, T. F., \& Lundan, S. M. (2016). The moderating role of local embeddedness on the performance of foreign and domestic firms in emerging markets. International Business Review.

Hair, J. F., Black, B., Babin, B., Anderson, R. E., Tatham, R. L., \& Black, W. C. (2010). Multivariate data analysis: A global perspective. Pearson Education Inc, New York (NY). 
Hawn, O. (2013). How social legitimacy helps overcome low home country legitimacy: Corporate social responsibility and emerging market multinationals. Paper Presented at the 2013 Academy of Management Annual Meeting, Orlando, Florida.

Held, K., \& Berg, N. (2014). Facing discrimination by host country nationals: Emerging market multinational enterprises in developed markets. In Verbeke. A, Tulder, R. V., \& Lundan, S. (ed.) Multinational Enterprises, Markets and Institutional Diversity (Progress in International Business Research, Volume 9) Emerald Group Publishing Limited, 417 - 441

Homburg, C., Stierl, M., \& Bornemann, T. (2013). Corporate social responsibility in business-tobusiness markets: How organizational customers account for supplier corporate social responsibility engagement. Journal of Marketing, 77(6), 54-72.

Hossain, M., \& Reaz, M. (2007). The determinants and characteristics of voluntary disclosure by Indian banking companies. Corporate Social Responsibility and Environmental Management, 14(5), 274-288.

Hoskisson, R. E., Kim, H., White, R. E., \& Tihanyi, L. (2004). A framework for understanding international diversification by business groups from emerging economies. Advances in International Management, 16, 137-163. 
Huang, C. L., \& Kung, F. H. (2010). Drivers of environmental disclosure and stakeholder expectation: Evidence from Taiwan. Journal of Business Ethics, 96(3), 435-451.

Hume, M. (2010). Compassion without action: Examining the young consumers consumption and attitude to sustainable consumption. Journal of World Business, 45(4), 385-394.

Ioannou, I., \& Serafeim, G. (2012). What drives corporate social performance and quest; The role of nation-level institutions. Journal of International Business Studies, 43(9), 834-864.

Johnsen, T., Howard, M., \& Miemczyk, J. (2014). Purchasing and supply chain management: A sustainability perspective. Routledge, New York (NY).

Julian, S. D., \& Ofori-dankwa, J. C. 2013. Financial resource availability and corporate social responsibility expenditures in a sub-Saharan economy: The institutional difference hypothesis. Strategic Management Journal, 34(11): 1314-1330.

Kansal, M., Joshi, M., \& Batra, G. S. (2014). Determinants of corporate social responsibility disclosures: Evidence from India. Advances in Accounting, 30(1), 217-229.

Khan, A., Muttakin, M. B., \& Siddiqui, J. (2013). Corporate governance and corporate social responsibility disclosures: Evidence from an emerging economy. Journal of Business Ethics, 114(2), 207-223. 
Khanna, T., \& Palepu, K. G. (2006). Emerging Giants: Building World-Class Companies in Developing Countries. Harvard Business Review, 84(10), 60-69.

Khanna, T., \& Palepu, K. (2000). The future of business groups in emerging markets: Long-run evidence from Chile. Academy of Management Journal,43(3), 268-285.

Kim, E. H., \& Lyon, T. P. (2014). Greenwash vs. brownwash: Exaggeration and undue modesty in corporate sustainability disclosure. Organization Science, 26(3), 705-723.

Kühn, A. L., Stiglbauer, M., \& Fifka, M. S. (2015). Contents and determinants of corporate social responsibility website reporting in sub-Saharan Africa: A seven- country study. Business \& Society. doi:10.1177/0007650315614234.

Lahiri, N., \& Narayanan, S. (2013). Vertical integration, innovation, and alliance portfolio size: Implications for firm performance. Strategic Management Journal, 34(9), 1042-1064.

Lee, S. Y. (2014). Samsung halts business with supplier in China on child labor concern. Retrieved September 24, 2015, from http://www.reuters.com/article/us-samsung-elec-child-labour-chinaidUSKBN0FJ05Y20140714 
Li, Q., Luo, W., Wang, Y., \& Wu, L. (2013). Firm performance, corporate ownership, and corporate social responsibility disclosure in China. Business Ethics: A European Review, 22(2), 159-173.

Li, S., Fetscherin, M., Alon, I., Lattemann, C., \& Yeh, K. (2010). Corporate social responsibility in emerging markets. Management International Review,50(5), 635-654.

Luo, Y., \& Tung, R. L. (2007). International expansion of emerging market enterprises: A springboard perspective. Journal of International Business Studies, 38(4), 481-498.

Ma, H., Zeng, S., Shen, G. Q., Lin, H., \& Chen, H. (2016). International diversification and corporate social responsibility: an empirical study of Chinese contractors. Management Decision, 54(3), 750-774

Madhok, A., \& Keyhani, M. (2012). Acquisitions as entrepreneurship: Asymmetries, opportunities, and the internationalization of multinationals from emerging economies. Global Strategy Journal, 2 (1), 26- 40.

Marano, V., Tashman, P., \& Kostova, T. (2016). Escaping the iron cage: Liabilities of origin and CSR reporting of emerging market multinational enterprises. Journal of International Business Studies. 
McKinsey \& Company. 2005. Global champions from emerging markets. The McKinsey

Quarterly, 2

McWilliams, A., Siegel, D. S., \& Wright, P. M. (2006). Corporate social responsibility: Strategic implications*. Journal of management studies, 43(1), 1-18.

McWilliams, A., \& Siegel, D. 2000. Corporate social performance and financial performance: Correlation or misspecification. Strategic Management Journal, 21(5): 603-609

Melo, T. (2012). Slack-resources hypothesis: a critical analysis under a multidimensional approach to corporate social performance. Social Responsibility Journal, 8(2), 257-269.

Menassa, E., \& Brodhäcker, M. (2015). The type and quantity of corporate social disclosures of German 'Universal' banks. Journal of Management \& Governance. doi:10.1007/s10997-0159336-y

Meyer, K. E., Estrin, S., Bhaumik, S. K., \& Peng, M. W. (2009). Institutions, resources, and entry strategies in emerging economies. Strategic management journal, 30(1), 61-80.

Mishra, S., \& Suar, D. (2010). Does corporate social responsibility influence firm performance of Indian companies? Journal of Business Ethics, 95(4), 571-601. 
Morhardt, J. E. (2010). Corporate social responsibility and sustainability reporting on the internet. Business Strategy and the Environment, 19(7), 436-452.

Moyeen, A., \& West, B. (2014). Promoting CSR to foster sustainable development: Attitudes and perceptions of managers in a developing country. Asia-Pacific Journal of Business Administration, 6(2), 97-115.

Nair, S. R., Demirbag, M., \& Mellahi, K. (2015). Reverse knowledge transfer from overseas acquisitions: a survey of Indian MNEs. Management International Review, 55(2), 277-301.

Oh, H., Bae, J., \& Kim, S. J. (2016). Can sinful firms benefit from advertising their CSR efforts? Adverse effect of advertising sinful firms' CSR engagements on firm performance. Journal of Business Ethics. doi: 10.1007/s10551-016-3072-3

Oh, W. Y., Cha, J., \& Chang, Y. K. (2015). Does ownership structure matter? The effects of insider and institutional ownership on corporate social responsibility. Journal of Business Ethics. doi: $10.1007 / \mathrm{s} 10551-015-2914-8$

Park, B. I., \& Ghauri, P. N. (2015). Determinants influencing CSR practices in small and medium sized MNE subsidiaries: A stakeholder perspective. Journal of World Business, 50(1), 192-204.

Pérez, A. (2015). Corporate reputation and CSR reporting to stakeholders: Gaps in the literature and future lines of research. Corporate Communications: An International Journal, 20(1), 11-29. 
Perks, K. J., Farache, F., Shukla, P., \& Berry, A. (2013). Communicating responsibility-practicing irresponsibility in CSR advertisements. Journal of Business Research, 66(10), 1881-1888.

Reimann, F., Ehrgott, M., Kaufmann, L., \& Carter, C. R. (2012). Local stakeholders and local legitimacy: MNEs' social strategies in emerging economies. Journal of International Management, 18(1), 1-17.

Shieh, G. (2011). Clarifying the role of mean centering in multicollinearity of interaction effects. British Journal of Mathematical and Statistical Psychology, 64(3), 462-477.

Su, W., Peng, M. W., Tan, W., \& Cheung, Y. L. (2016). The signaling effect of corporate social responsibility in emerging economies. Journal of Business Ethics, 134(3) 479-491.

Suchman, M. C. (1995). Managing legitimacy: Strategic and institutional approaches. Academy of Management Review, 20(3), 571-610.

The Economist. (2011). The Tata group: Out of India. Retrieved January 12, 2016, http://www.economist.com/node/18285497

The Economist. (2006). Mittal's victory. Retrieved January 12, 2016, from http://www.economist.com/node/7106110 
Thijssens, T., Bollen, L., \& Hassink, H. (2015). Secondary stakeholder influence on CSR disclosure: An application of stakeholder salience theory. Journal of Business Ethics, 132(4), 873891.

Vidaver-Cohen, D., Gomez, C., \& Colwell, S. R. (2015). Country-of-origin effects and corporate reputation in multinational firms: Exploratory research in Latin America. Corporate Reputation Review, 18(3), 131-155.

Young, S., \& Marais, M. (2012). A multi-level perspective of CSR reporting: The implications of national institutions and industry risk characteristics. Corporate Governance: An International Review, 20(5), 432-450.

Xia, J., Ma, X., Lu, J. W., \& Yiu, D. W. (2014). Outward foreign direct investment by emerging market firms: A resource dependence logic. Strategic management journal, 35(9), 1343-1363.

Zheng, Q., Luo, Y., \& Maksimov, V. (2015). Achieving legitimacy through corporate social responsibility: The case of emerging economy firms. Journal of World Business, 50(3), 389-403. 
Communicating CSR Practices

Table 1 Descriptive Statistics

\begin{tabular}{|c|c|c|c|c|c|c|c|c|c|}
\hline & & 1 & 2 & 3 & 4 & 5 & 6 & 7 & 8 \\
\hline 1 & CSR disclosure & 1 & & & & & & & \\
\hline 2 & FDI/asset & $0.33 * * *$ & 1 & & & & & & \\
\hline 3 & $\begin{array}{l}\text { Market Seeking } \\
\text { Motive }\end{array}$ & $0.21 * * *$ & $0.14 * * *$ & 1 & & & & & \\
\hline 4 & LnSales & $0.25 * * *$ & $0.16^{* * *}$ & $0.12 * * *$ & 1 & & & & \\
\hline 5 & LnAge & 0.003 & $0.09 * * *$ & $0.06 * *$ & $0.26 * * *$ & 1 & & & \\
\hline 6 & Industry & 0.04 & 0.03 & 0.01 & 0.009 & 0.02 & 1 & & \\
\hline 7 & $\begin{array}{l}\text { Business Group } \\
\text { Affiliation }\end{array}$ & $0.14 * * *$ & $0.19 * * *$ & $0.14 * * *$ & $0.34 * * *$ & $0.15^{* * *}$ & 0.001 & 1 & \\
\hline 8 & Profitability & $0.13 * * *$ & $0.16 * * *$ & $0.08 * *$ & $0.10 * * *$ & 0.005 & 0.002 & $0.07 * *$ & 1 \\
\hline
\end{tabular}

$* * * \mathrm{p}<0.010 ; * * \mathrm{p}<0.050, * \mathrm{p}<0.100$ 
Table 2 Results of multiple linear regression

\begin{tabular}{|c|c|c|c|}
\hline & Model 1 & Model 2 & Model 3 \\
\hline & Coefficient & Coefficient & Coefficient \\
\hline Intercept & $\begin{array}{l}1.65^{* * * *} \\
(0.05)\end{array}$ & $\begin{array}{l}1.35^{* * * *} \\
(0.08)\end{array}$ & $\begin{array}{l}1.37 * * * \\
(0.08)\end{array}$ \\
\hline FDI/asset & & $\begin{array}{l}0.06^{* * *} \\
(0.01)\end{array}$ & $\begin{array}{l}0.05^{* * *} \\
(0.01)\end{array}$ \\
\hline Market Seeking Motive & & $\begin{array}{l}0.19 * * * \\
(0.06)\end{array}$ & $\begin{array}{l}0.19^{* * *} \\
(0.06)\end{array}$ \\
\hline BG Affiliation*FDI/asset & & & $\begin{array}{l}0.03^{* * *} \\
(0.01)\end{array}$ \\
\hline LnSales & $\begin{array}{l}0.04^{* * *} \\
(0.01)\end{array}$ & $\begin{array}{l}0.04^{* * *} \\
(0.01)\end{array}$ & $\begin{array}{l}0.04^{* * *} \\
(0.01)\end{array}$ \\
\hline LnAge & $\begin{array}{l}0.03 \\
(0.02)\end{array}$ & $\begin{array}{l}0.02 \\
(0.02)\end{array}$ & $\begin{array}{l}0.02 \\
(0.02)\end{array}$ \\
\hline Industry & $\begin{array}{l}0.05 \\
(0.03)\end{array}$ & $\begin{array}{l}0.06 \\
(0.04)\end{array}$ & $\begin{array}{l}0.06 \\
(0.04)\end{array}$ \\
\hline Profitability & $\begin{array}{l}1.27 * * * \\
(0.34)\end{array}$ & $\begin{array}{l}1.25 * * * \\
(0.33)\end{array}$ & $\begin{array}{l}1.25 * * * \\
(0.33)\end{array}$ \\
\hline Business Group Affiliation & $\begin{array}{l}0.09^{* * * *} \\
(0.02)\end{array}$ & $\begin{array}{l}0.10^{* * * *} \\
(0.03)\end{array}$ & $\begin{array}{l}0.10^{* * * *} \\
(0.03)\end{array}$ \\
\hline
\end{tabular}


Communicating CSR Practices

\begin{tabular}{|l|l|l|l|}
\hline Overall R square & 0.13 & 0.16 & 0.17 \\
\hline
\end{tabular}

$* * * \mathrm{p}<0.001 ; *^{*} \mathrm{p}<0.050,{ }^{*} \mathrm{p}<0.100$; s.e in parenthesis 